\title{
A Simple Zeolite-based Treatment of Soya Bean Oil Mill Wastewater for Irrigation Purposes
}

\author{
Rose Erdoo Kukwa ${ }^{1,}$, , Benjamin Ishwah ${ }^{1}$, Ahola David Oklo ${ }^{1}$, Donald Tyoker Kukwa ${ }^{2}$, \\ Fredrick Teghtegh $\mathrm{Samoh}^{3}$, Aondoakaa Steve Nomor ${ }^{1}$ \\ ${ }^{1}$ Department of Chemistry, Faculty of Science, Benue State University, Makurdi, Benue State, Nigeria \\ ${ }^{2}$ Department of Engineering and the Built Environment, Durban University of Technology, Durban, South Africa \\ ${ }^{3}$ Department of Chemistry, University of Ilorin, Ilorin, Kwara State, Nigeria \\ Email address: \\ erdoo.rose@gmail.com (R. E. Kukwa), Ishwahlizer@gmail.com (B. Ishwah), oklodahola@gmail.com (A. D. Oklo), \\ tyokerdoo@gmail.com (D. T. Kukwa), Samoh.ft@unilorin.edu.ng (F. T. Samoh), nomorsteve@gmail.com (A. S. Nomor) \\ ${ }^{*}$ Corresponding author
}

\section{To cite this article:}

Rose Erdoo Kukwa, Benjamin Ishwah, Ahola David Oklo, Donald Tyoker Kukwa, Fredrick Teghtegh Samoh, Aondoakaa Steve Nomor. A Simple Zeolite-based Treatment of Soya Bean Oil Mill Wastewater for Irrigation Purposes. American Journal of Chemical Engineering. Vol. 8, No. 1, 2020, pp. 19-26. doi: 10.11648/j.ajche.20200801.14

Received: January 25, 2020; Accepted: February 19, 2020; Published: March 10, 2020

\begin{abstract}
Soya bean oil mill wastewater (SOMW) is a liquid waste obtained from the soya bean oil industry with several environmental problems due to its high amount of toxic pollutants. This research work is aimed at assessing the feasibility and suitability of using a zeolite-based method for the treatment of soya bean oil mill wastewater for irrigation purposes. In this study, successive columns containing different types of solid-state materials were used to investigate the treatment efficiency of SOMW using physicochemical parameters; $\mathrm{pH}$ was determined using a $\mathrm{pH}$ meter, Turbidity determined using Turbidity meter. The concentration of $\mathrm{Na}^{+}, \mathrm{Ca}^{2+}, \mathrm{Mg}^{2+}, \mathrm{K}^{+}$were determined using Flame photometer and the concentration of $\mathrm{NO}_{3}{ }^{-}$, $\mathrm{SO}_{4}^{2-}, \mathrm{PO}_{4}^{3-}$ were determined using Oxygen Analyzer. Zeolite was characterized using Advanced Powdered X-ray diffractometer, energy dispersive spectrometer and Fourier Transformed Infrared and the fine sand characterized using an integrated X-ray Analyzer. The treatment columns were packed with fine sand, zeolite and zeolite/fine sand composite. The treatment decreased the concentrations of $\mathrm{Na}^{+}, \mathrm{Ca}^{2+}, \mathrm{Mg}^{2+}, \mathrm{K}^{+}, \mathrm{NO}_{3}{ }^{-}, \mathrm{SO}_{4}{ }^{2-}, \mathrm{PO}_{4}{ }^{3-}$ and $\mathrm{pH}$ by mean percentages of 80.5, 29.6, $81.0,2.1,66.5,41.4,47.4$ and $42.3 \%$, respectively. The turbidity of the soya bean oil mill wastewater decreased by $72.5 \%$. Most contaminants were removed in the soya bean oil wastewater in the zeolite/sand composite column. This decrease in the concentration of the pollutants could be attributed to the high sorption and ion exchange capacity of the solid-state materials used. This simple zeolite-based method is promising technology for the treatment of industrial wastewaters from oil processing industries for irrigational purposes.
\end{abstract}

Keywords: Zeolite, Soya Bean Oil Mill Wastewater, Physical Precipitation, Fine Sand, Column

\section{Introduction}

Nigeria is considered to be an agrarian State with tones of agricultural products such as; groundnut, soya bean, sorghum, maize and millet. They are produced yearly and later processed into edible oils thereby generating large amount of Wastewater [1]. In most developing countries like Nigeria, wastewater obtained from these agricultural processing industries poses a major threat to humans, plants and aquatic lives when disposed into the environment without prior treatment [1]. Their treatment is thus essential before disposal [2]. The Vegetable oil effluent consists mainly of fats, oils, greases (FOG), nitrate, and sulphate and phosphates [3].

The processes that results to these industrial wastewaters from edible oil processing are known but not limited to degumming, deacidification, bleaching, hydrogenation, deodorization, winterinsing and the neutralization steps. Sodium salts of free fatty acid (soap stocks) are splitted through the use of sulphuric acid in the neutralization step, 
generating highly acidic and oily wastewaters. Its characteristics depend largely on the type of oil processed as well as the processing method, resulting in high amount of chemical oxygen demand (COD), oil and grease, sulphate and phosphate content, thus leading to high inorganic as well as organic loading of the relevant wastewater $[4,5]$. The degumming operation, removes phosphatides. Some of the phosphatides in oils are readily hydrated hence water or steam is used to precipitate the phosphatides. The calcium and magnesium salts of phosphatides or lysophosphatidic acid are not hydrated by water but can be hydrated by alkali or acid [6].

Wastewaters from soya oil mill production are characterized by the following features and components: color ranging from intensive yellow to black, strong soya oil odor, high content of polyphenols (up to $80 \mathrm{mg} / \mathrm{L}$ ), high content of solid matter (total solids up to $102.5 \mathrm{mg} / \mathrm{L}$ ) and high content of oil (up to $30 \mathrm{mg} / \mathrm{L}$ ). It is typically high in organic content, resulting in a biochemical oxygen demand (BOD) of $40-100 \mathrm{mg} / \mathrm{L}$ ) and a chemical oxygen demand (COD) of $50-200 \mathrm{mg} / \mathrm{L}$. The wastewater has a $\mathrm{pH}$ range of 4.5- 5.6, fat residues $(50-100 \mathrm{mg} / \mathrm{L})$, organic nitrogen $(50-80$ $\mathrm{mg} / \mathrm{L}$ ), and ash residues (40 to $50 \mathrm{mg} / \mathrm{L}$ ) $[7,8] . \mathrm{Na}^{+}, \mathrm{Ca}^{2+}$, $\mathrm{Mg}^{2+}$ and $\mathrm{K}^{+}$are the main ionic species present in the soya bean oil mill wastewater. In recent years, there has been increased attention directed towards finding the best methods to treat vegetable oil wastewater and toward recycling both the organic matter and nutritive elements for crop production $[9,10]$.

Various techniques have been developed for treatment of oil mill wastewaters. The treatment methods may be physical, chemical or biological in nature. Some of which include; solvent extraction, adsorption, chemical oxidation, foam filtration, filtration, ion exchange, sedimentation, membrane processes, stepwise coagulation, lime softening, coagulation, electrochemical processes, electrocoagulation, and chemical precipitation [11]. Most of these methods have drawbacks; including low efficiency for removal of trace concentration of pollutants in case of chemical/biological oxidation, electrolysis, ion exchange and solvent extraction [12]. Coagulation and precipitation processes produce large amount of sludge and require $\mathrm{pH}$ control [13]. Ozonation removes color from wastewater without decreasing the COD. Membrane processes suffer the problem of fouling of the membrane used [14]. Many of these processes lack in cost effectiveness with high energy intensive processing [15]. On the other hand, adsorption process has many advantages over the other processes. Some of which include; low operation cost, high flexibility, simple design and operation, easy automation, lack of sensitivity to toxic pollutants and the capability of operation at very low concentration, environmentally friendly, less investment in terms of initial cost [16]. Activated carbon had been the primary adsorbent of use over time because of its high capacity for removal of various pollutants. However, it brings with it the disadvantage of its high price and its high regeneration cost [17]. The use of zeolite is one of the most effective methods in wastewater treatment. Zeolites are environmentally and economically acceptable hydrated aluminosilicate materials with exceptional ion-exchange and sorption properties. They are naturally occurring crystalline aluminosilicate minerals that are derived from silica $\left(\mathrm{SiO}_{2}\right)$ by the isomorphous substitution of $\mathrm{SiO}_{4}$ - tetrahedra by $\mathrm{AlO}_{4}$ - tetrahedra. Recent investigations of natural and synthetic zeolites as adsorbents in water and wastewater treatment, their properties and possible modification of the zeolites have been a subject of many studies [18]. The use of zeolites in wastewater treatment has been reported by many researchers to be effective. In this present study, a simple zeolite low-cost method was used for Soya bean oil mill wastewater treatment. This was achieved by using successive columns of fine sand, zeolite and zeolite/sand composite.

\section{Materials and Methods}

\subsection{Analytical Methods}

Soluble $\mathrm{Na}^{+}, \mathrm{Ca}^{2+}, \mathrm{Mg}^{2+}$ and $\mathrm{K}^{+}$were determined using flame photometer (jenway PFP7). $\mathrm{pH}$ was determined using ( $\mathrm{pH} 501$ Eutech). Turbidity was determined using turbidity meter (NT-100). Zeolite Y was characterized using Advance powdered diffractometer (Bruker D8), FTIR and EDS, fine sand characterized using X-ray fluorescence spectrometer (ARL 9900 OASIS). Phosphate, nitrate and sulphate were determined using a direct reading spectrometer (JPB-607) portal.

\subsection{Study Area}

This research work was conducted in Makurdi town, the headquarters of Benue State, Nigeria. The town is located between latitude $7^{\circ} 38^{\prime} \mathrm{N}-7^{\circ} 50^{\prime} \mathrm{N}$, and longitude $8^{\circ} 24^{\prime} \mathrm{E}$ and $8^{\circ} 38^{\prime} \mathrm{E}$ and 104 meters elevation. It is situated in the Benue valley in the North Central region of Nigeria. It is traversed by the second largest river in the country, the River Benue.

\subsection{Sample Collection}

Twenty liters (20.0L) of fresh soya bean oil mill wastewater was collected (using sterile plastic container) at Seraph oil mills, Nigeria Limited, which is located at $\mathrm{Km} 7$ Gboko Road Makurdi, Benue State. The soya bean oil mill wastewater was then transported immediately to Chemistry laboratory at Benue State University and refrigerated at $35^{\circ} \mathrm{C}$ prior to analysis. Fine sand was purchased at pillar poole Nigeria, limited. Zeolite $\mathrm{Y}$ was earlier synthesized in the Department of Chemistry Laboratory, Loughborough University, Loughborough, Leicestershire, United Kingdom.

\subsection{Sample Digestion}

The Environmental Protection Agency (EPA) vigorous digestion method described by Gregg (1989) was adopted. The sample digestion was done using nitric acid and heated until digestion completed. The sample was filtered and transferred into $100 \mathrm{~mL}$ volumetric flask and made to mark 
with distilled water. The wastewater digest was used for flame photometric analysis [19].

\subsection{Physical Precipitation of Soya Bean Oil Mill Wastewater}

Physical separation was carried out using glass cylinders with diameter $10 \mathrm{~cm}$ and length $20 \mathrm{~cm}$. After $5 \mathrm{~h}$ of gravity separation, two kinds of suspended solids were observed: a floating part and a precipitated part. The floating part was decanted and the precipitate filtered using filter paper and a less turbid sample was obtained [20].

\subsection{Soya Bean Oil Mill Wastewater Treatment Using Successive Steps}

The soya bean oil mill wastewater (Soap stock) was passed through three designed treatment steps, following physical separation. Each treatment consists of successive column containing different solid-state materials. The columns were made of transparent glass material with an internal diameter of $2 \mathrm{~cm}$ and a length of $20 \mathrm{~cm}$. The columns were sealed from the bottom using two pieces of gauze fabric firmly held by strings and tape. The columns were packed with solidstate materials to $15 \mathrm{~cm}$ height. The packing process was done in $5 \mathrm{~cm}$ increments to avoid segregation of particles. The columns were mounted vertically on a wooden holder in the laboratory. Each treatment system was replicated three times. The contact times between the soya bean oil mill wastewater and solid-state materials were $1 \mathrm{~h}$ for fine sand, 2 $\mathrm{h}$ for zeolite and $4 \mathrm{~h}$ for the fine zeolite/sand composite. The physicochemical parameters used to evaluate the treatment efficiency for each method were $\mathrm{pH}$, phosphate, turbidity, sulphate, nitrate and metal ions concentration [20].

\subsection{Characterization of Zeolite $Y$}

Zeolite Y was synthesized and characterized using PXRD, EDS and FTIR. The PXRD used was a Bruker D8 Advance diffractometer operating with a copper X-ray tube, a monochromator with a Linx Eye detector. The PXRD data were collected using $\mathrm{Cu} \mathrm{K} \alpha_{1}(1.5406 \AA)$ radiation, over the $2 \theta$ range between $5-60^{\circ}$ using a step size of $0.022^{\circ}$ for 43 minutes. The EDS spectrum was produced on an EDAX Pheonix, EDX with a Carl Zeiss 1530 VP spectrometer. The samples were sprinkled onto $12 \mathrm{~mm}$ aluminium stubs using "carbon sticky tabs". These were then gold coated using an Emitech SC 7640 gold/palladium sputter coater to reduce the static charges during the analysis.

The PerkinElmer paragon 1000 FTIR spectrophotometer was used to collect FTIR data for the sample. The sample was prepared by making discs of a small amount of the sample ( $\square 3 \mathrm{mg}$ ) in $\mathrm{KBr}$ and measurements were carried out over IR region of $1200-400 \mathrm{~cm}^{-1}$ for the zeolite. A background spectrum was measured before the sample to compensate for atmospheric conditions around the FTIR instrument
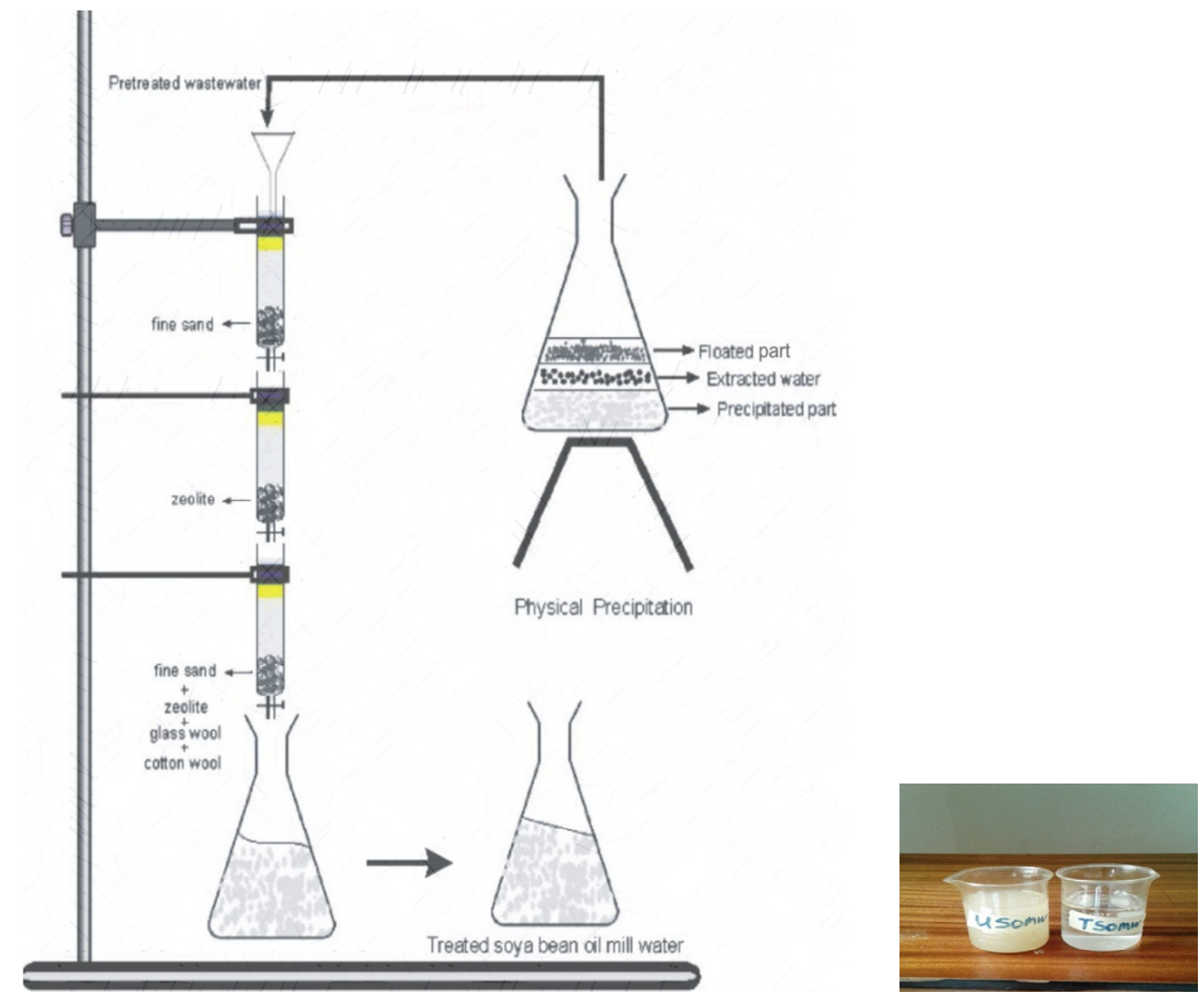

Figure 1. Diagram illustrating the components of the soya bean oil mill wastewater (SOMW) treatment model and the appearance of the treated sample compared to untreated sample. 


\section{Results and Discussion}

\subsection{Chemical Composition of Fine Sand}

The chemical composition of the fine sand used in this present study was determined by X-ray fluorescence spectrometer (ARL 9900 OASIS Model) as shown in (Table 1). Silicon dioxide was found to be the predominant oxide, 92.49\%. Other oxides present were $\mathrm{Al}_{2} \mathrm{O}_{3} 7.44 \%, \mathrm{CaO} 0.06 \%$ and $\mathrm{MgO} 0.09 \%$. The silicon to aluminum ratio of the fine sand used was 12.40 . This characterization data obtained is in line with earlier investigation reported [21]

Table 1. Chemical composition of fine sand (XRF Spectrometer).

\begin{tabular}{ll}
\hline Compounds/elements & \% Weight \\
\hline $\mathrm{SiO}_{2}$ & 92.49 \\
$\mathrm{Al}_{2} \mathrm{O}_{3}$ & 7.44 \\
$\mathrm{Fe}_{2} \mathrm{O}_{3}$ & $\mathrm{ND}$ \\
$\mathrm{CaO}$ & 0.06 \\
$\mathrm{MgO}$ & 0.09 \\
$\mathrm{~K}_{2} \mathrm{O}$ & $\mathrm{ND}$ \\
\hline
\end{tabular}

Key ND: Not detected

\subsection{Synthesis of Zeolite $Y$}

SEM-EDS
The elemental composition of zeolite $\mathrm{Y}$ was determined using energy dispersive spectroscopy (EDAX Pheonix model) as shown in (Table 2). The result revealed that zeolite $\mathrm{Y}$ consist of 48 7\% Oxygen, 9.2\% Sodium, 11.2\% Aluminum and $30.7 \%$ Silicon. The $\mathrm{Si} / \mathrm{Al}$ ratio $(2.7 \%)$ calculated was found to be in good agreement with the data obtained from PXRD (2.4\%) as calculated from the molecular formula of the zeolite $\mathrm{Y}\left(\mathrm{Na}_{54.91} \mathrm{Al}_{56} \mathrm{Si}_{136} \mathrm{O}_{384}\right)$.

Table 2. Elemental composition of the synthesized Zeolite Y (EDS).

\begin{tabular}{ll}
\hline Elements & \% Weight \\
\hline $\mathrm{O}$ & $48.7 \pm 0.07$ \\
$\mathrm{Na}$ & $9.2 \pm 0.04$ \\
$\mathrm{Al}$ & $11.50 \pm 0.0$ \\
$\mathrm{Si}$ & $30.7 \pm 0.1$ \\
$\mathrm{Si} / \mathrm{Al}$ & 2.7 \\
\hline
\end{tabular}

PXRD

The PXRD data compared against the ICDD database for the theoretical phases showed good agreement that the targeted zeolite $\mathrm{Y}$ was formed as clearly seen from the matched patterns (figure 2). The PXRD patterns for the zeolite $\mathrm{Y}$ was a single crystalline phase with high degree of crystallinity.

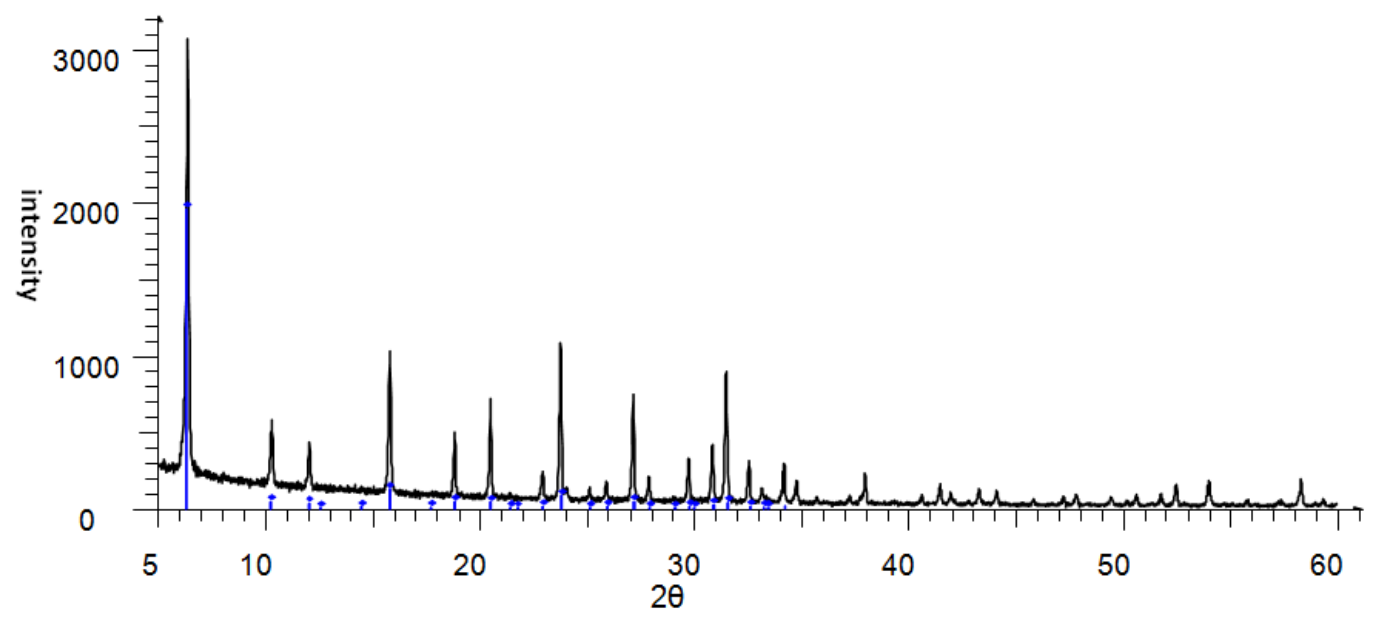

Figure 2. PXRD pattern for zeolite Y (experimental pattern) matched with the reference pattern 01-070-4285 (vertical tick marks), anhydrous formula $\left(\mathrm{Na}_{54.91} \mathrm{Al}_{56} \mathrm{Si}_{136} \mathrm{O}_{384}\right)$.

\section{FTIR}

A broad band was observed in the region $1019 \mathrm{~cm}^{-1}$ which was attributed to the asymmetric vibrations of $\mathrm{Si}-\mathrm{O}$ bridging and Si-O non-bridging bonds. The band in the range $717 \mathrm{~cm}^{-1}$ is due to the symmetric stretching of internal vibrations while the internal vibrations due to the bending of the T-O tetrahedra occurred between $455 \mathrm{~cm}^{-1}$. Vibrations of the double six rings (D6R) connecting the sodalite cages occurred between $579 \mathrm{~cm}^{-1}$ while that around $626 \mathrm{~cm}^{-1}$ is assigned to the symmetric stretching of external T-O linkages in the zeolite. The band at $1150 \mathrm{~cm}^{-1}$ was attributed to the asymmetric stretching of external T-O linkages in the zeolite respectively [21].

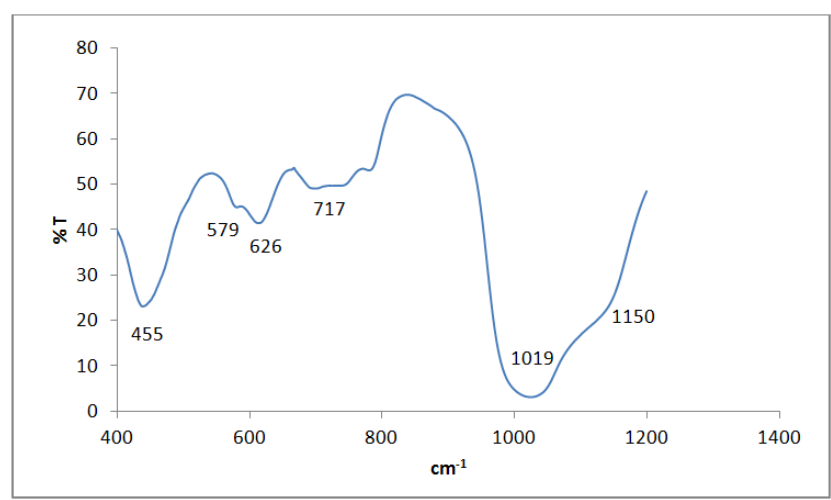

Figure 3. FTIR spectrum for the synthesised zeolite $Y$. 


\subsection{Characterization Results of Untreated Soya Bean Oil Mill Wastewater}

The untreated soya bean oil mill wastewater was

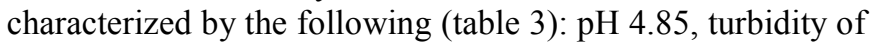
$200 \mathrm{NTU}, \mathrm{NO}_{3}^{-}$content of $35.80 \mathrm{mg} / \mathrm{L}, \mathrm{PO}_{4}^{3-}$ content of $4.75 \mathrm{mg} / \mathrm{L}$ and $\mathrm{SO}_{4}^{2-}$ content of $85.20 \mathrm{mg} / \mathrm{L}$. The concentrations of $\mathrm{Na}^{+}, \mathrm{Ca}^{2+}, \mathrm{Mg}^{2+}$ and $\mathrm{K}^{+}$were $12.0703 \mathrm{mg} / \mathrm{L}$, $10.5520 \mathrm{mg} / \mathrm{L}, 7.2833 \mathrm{mg} / \mathrm{L}$ and $10.5520 \mathrm{mg} / \mathrm{L}$ respectively. The results obtained were far above the maximum allowable concentration limits recommended for irrigation purposes by standard regulatory bodies like FOA (2010), EPA (2011) and WHO (2016). This implies that this soya bean oil water could not be used for agricultural purposes [22, 23]. Potassium was the predominant inorganic substance found in the untreated soya bean oil mill wastewater with a concentration of $15.5915 \mathrm{mg} / \mathrm{L}$, it was considered been the main cause of SOMW salinity, similar results were obtained by some researchers $[24,25]$.

Table 3. Average physicochemical characteristics of untreated and treated soya bean oil mill wastewater.

\begin{tabular}{llllll}
\hline Parameters & Untreated soya bean oil mill wastewater & Treated soya bean oil mill wastewater & FAO (2011) & WHO (2010) & $\begin{array}{l}\text { EPA } \\
(\mathbf{2 0 1 6})\end{array}$ \\
\hline $\mathrm{pH}$ & $4.85 \pm 0.0$ & $6.90 \pm 0.2$ & $6.5-9.0$ & $6.0-9.0$ \\
$\mathrm{Turb} .(\mathrm{NTU})$ & $200 \pm 0.2$ & 55.0 & 50.0 & 40.0 & $7.3-8.5$ \\
$\mathrm{Ca}^{2+}(\mathrm{mg} / \mathrm{L})$ & $10.5520 \pm 0.0$ & $7.4026 \pm 0.1$ & 5.0 & $6.0-7.0$ \\
$\mathrm{~K}^{+}(\mathrm{mg} / \mathrm{L})$ & $15.5915 \pm 0.0$ & $15.2755 \pm 0.4$ & $5.0-7.0$ & 5.0 & 4.5 \\
$\mathrm{Mg}^{2+}(\mathrm{mg} / \mathrm{L})$ & $7.2833 \pm 0.0$ & $1.3815 \pm 0.2$ & 2.0 & 2.0 & 5.0 \\
$\mathrm{Na}^{+}(\mathrm{mg} / \mathrm{L})$ & $12.0703 \pm 0.2$ & $2.4241 \pm 0.1$ & 6.0 & 2.0 & 2.0 \\
$\mathrm{NO}_{3}^{-}(\mathrm{mg} / \mathrm{L})$ & $35.80 \pm 0.3$ & $12.0 \pm 0.2$ & 20.0 & 10.0 & $3.0-4.0$ \\
$\mathrm{SO}_{4}^{2-}(\mathrm{mg} / \mathrm{L})$ & $85.20 \pm 0.1$ & $50.03 \pm 0.1$ & 250.0 & 250.0 & 20.0 \\
$\mathrm{PO}_{4}^{3-}(\mathrm{mg} / \mathrm{L})$ & $4.75 \pm 0.2$ & $2.50 \pm 0.4$ & 2.0 & 2.0 & 250.0 \\
\hline
\end{tabular}

\subsection{Soya Bean Oil Mill Wastewater Treatment Using Each Treatment Step}

Physical precipitation

The treatment of SOMW by physical precipitation revealed a decreased acidity by $1.03 \%, \mathrm{Mg}^{2+}$ concentration by $3.62 \%$, turbidity by $12.50 \% \mathrm{SO}_{4}^{2-}$ by $0.00 \%, \mathrm{PO}_{4}^{3-}$ by $3.16 \%$ and $\mathrm{NO}_{3}^{-}$by $15.08 \%$ respectively. The concentrations of the studied cations: $\mathrm{Na}^{+}, \mathrm{K}^{+}, \mathrm{Ca}^{2+}$ and $\mathrm{Mg}^{2+}$ decreased by $0.00,0.12,0.02$ and $3.62 \%$ respectively. This could be attributed to the fact that the concentration of the cations and anions has been reduced through gravity settling, decantation and filtration [26].

Fine sand treatment

Fine sand treatment decreased the $\mathrm{pH}$ by $5.88 \%$, turbidity by $24.57, \mathrm{SO}_{4}^{2-}$ by $0.37, \mathrm{PO}_{4}^{3-}$ by $12.39 \%$ and $\mathrm{NO}_{3}^{-}$by $26.64 \%$ respectively. The concentrations of the studied cations: $\mathrm{Na}^{+}$. $\mathrm{K}^{+}, \mathrm{Ca}^{2+}$ and $\mathrm{Mg}^{2+}$ decreased by $41.67,0.13,22.18,7.40 \%$ respectively. The decrease could be attributed to the fact that sand consist of $92.49 \%$ by weight $\mathrm{SiO}_{2}$ and $7.44 \% \mathrm{Al}_{2} \mathrm{O}_{3}$ given $\mathrm{Si} / \mathrm{Al}$ of $12.4 \%$. This clearly shows that in addition to ion exchange, the sand had the capacity to effectively adsorb these toxic substances, thereby decreasing their concentrations from the wastewater [27].

Zeolite Treatment

Zeolite treatment further decreased the acidity by $23.88 \%$ and turbidity by $39.39 \%$. The concentration of the studied cations and anions such as $\mathrm{Na}^{+} \mathrm{K}^{+}, \mathrm{Ca}^{2+}, \mathrm{Mg}^{2+} \mathrm{SO}_{4}^{2-}, \mathrm{PO}_{4}^{3-}$ and $\mathrm{NO}_{3}^{-}$decreased by $23.07,0.77,2.31,68.00,25.09,16.88$ and $35.43 \%$ respectively. The decrease in the toxic concentration of the wastewater could be attributed to the ion exchange capacity of the zeolite material [28].

Zeolite/sand composite

The zeolite/sand composite treatment (treatment 4) decreased the anions and cations concentration of $\mathrm{Na}^{+} \mathrm{K}^{+}$, $\mathrm{Ca}^{2+}$, and $\mathrm{Mg}^{2+}, \mathrm{SO}_{4}^{2-}, \mathrm{PO}_{4}^{3-}$ and $\mathrm{NO}_{3}^{-}$by $55.35 \%, 1.29,7.73$, $33.65,17.03,25.37$ and $16.66 \%$ respectively. The $\mathrm{pH}$ also decreased by 2.89 and turbidity to $1.23 \%$. Most contaminants were removed from SOMW using treatment 3 and 4 (Zeolite and zeolite/sand composite treatment), this could be attributed to the high sorption and ion exchange affinity of zeolite material [28, 29]. Similar results were reported by some researchers on agricultural wastewater treatment using coagulation, flotation and chemical treatment [30].

Table 4. Effects of the different treatment columns on soya bean oil mill wastewater physicochemical parameters).

\begin{tabular}{|c|c|c|c|c|c|c|c|c|c|c|}
\hline \multirow{2}{*}{ NO. } & \multirow{2}{*}{ Treatment method } & \multicolumn{9}{|c|}{ Physicochemical parameters after each treatment (Mean) } \\
\hline & & pH & Turb. (NTU) & $\mathrm{Na}^{+}(\mathrm{mg} / \mathrm{L})$ & $\mathrm{Ca}^{2+}(\mathrm{mg} / \mathrm{L})$ & $\mathrm{Mg}^{2+}(\mathrm{mg} / \mathrm{L})$ & $\mathbf{K}^{+}(\mathbf{m g} / \mathbf{L})$ & $\mathrm{NO}_{3}^{-}(\mathrm{mg} / \mathrm{L})$ & $\mathrm{SO}_{4}^{2-}(\mathrm{mg} / \mathrm{L})$ & $\mathrm{PO}_{4}^{3-}(\mathrm{mg} / \mathrm{L})$ \\
\hline 1 & Physical precipitation & 4.8 & 175.0 & 12.07 & 10.55 & 7.02 & 15.61 & 30.40 & 85.20 & 4.60 \\
\hline 2 & Fine sand & 5.1 & 132.0 & 7.04 & 8.21 & 6.50 & 15.59 & 22.30 & 80.50 & 4.03 \\
\hline 3 & Zeolite & 6.7 & 80.0 & 5.42 & 8.02 & 2.08 & 15.47 & 14.40 & 60.30 & 3.35 \\
\hline 4 & Zeolite/fine sand & 6.9 & 55.0 & 2.42 & 7.40 & 1.38 & 15.27 & 12.00 & 50.03 & 2.50 \\
\hline
\end{tabular}

\subsection{Treatment Effect on SOMW Using the Entire Successive Treatment}

The soya bean oil mill wastewater treatment using successive columns containing solid state materials; fine sand, zeolite and zeolite/sand composite (table 4) decreased the toxic concentrations of $\mathrm{Na}^{+}, \mathrm{Ca}^{2+}, \mathrm{Mg}^{2+}, \mathrm{K}^{+}, \mathrm{NO}_{3}^{-}, \mathrm{SO}_{4}^{2-}$, $\mathrm{PO}_{4}^{3-}$ and $\mathrm{pH}$ by mean percentages of $80.5,29.6,81.0,2.1$, 
$66.5,41.4,47.4$ and $42.3 \%$ respectively. The turbidity of the soya bean oil mill wastewater decreased by $72.5 \%$. The predominant cation in the untreated soya bean oil mill wastewater is potassium which is believed to be the main cause of increased salinity [31, 32]. Using zeolite $\mathrm{Y}$ for desalination is considered a valid method for SOMW treatment since the toxic concentrations of $\mathrm{Na}^{+}, \mathrm{Ca}^{2+}, \mathrm{Mg}^{2+}$, $\mathrm{K}^{+}$were greatly decreased. In this study, $41.4 \%$ of $\mathrm{K}^{+}$was removed by passing the SOMW through the zeolite/sand composite column, similar to the findings reported by some researchers [32]. The order of affinity of Zeolite $\mathrm{Y}$ to the alkali and alkaline earth metal cations is as follows: $\mathrm{K}^{+}>$ $\mathrm{Ca}^{2+}>\mathrm{Na}^{+}>\mathrm{Mg}^{2+}$.

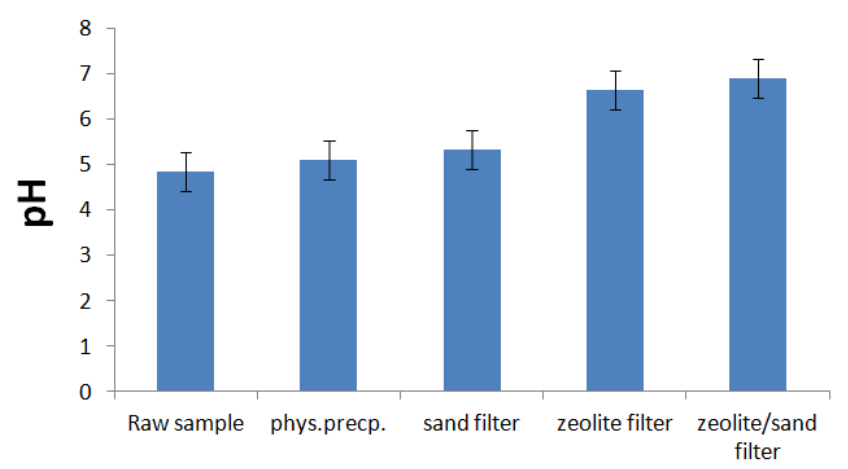

Figure 4. Impact of different treatment steps on soya bean oil mill wastewater on $\mathrm{pH}$

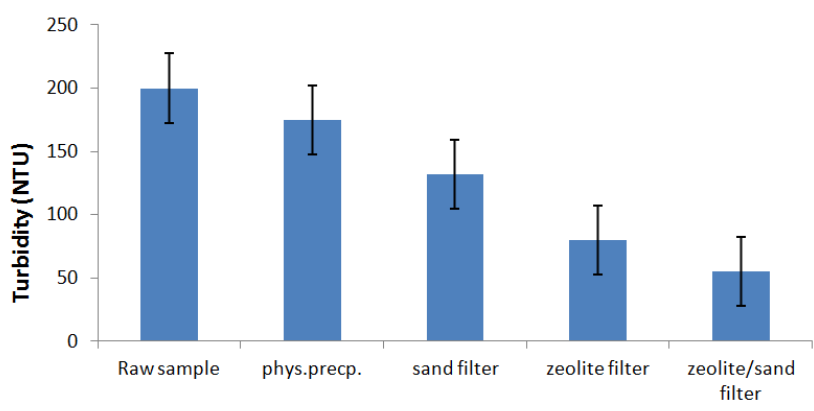

Figure 5. Impact of different treatment steps on soya bean oil mill wastewater on Turbidity (NTU).

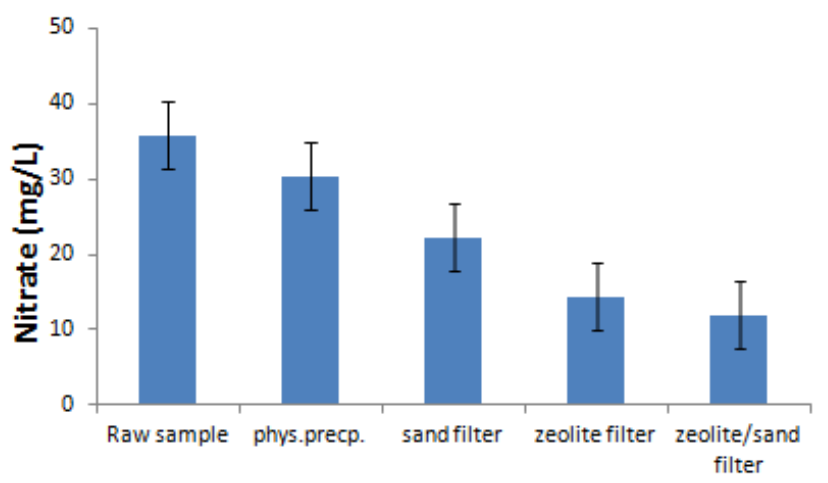

Figure 6. Impact of different treatment steps on soya bean oil mill wastewater on Nitrate $(\mathrm{mg} / \mathrm{L})$

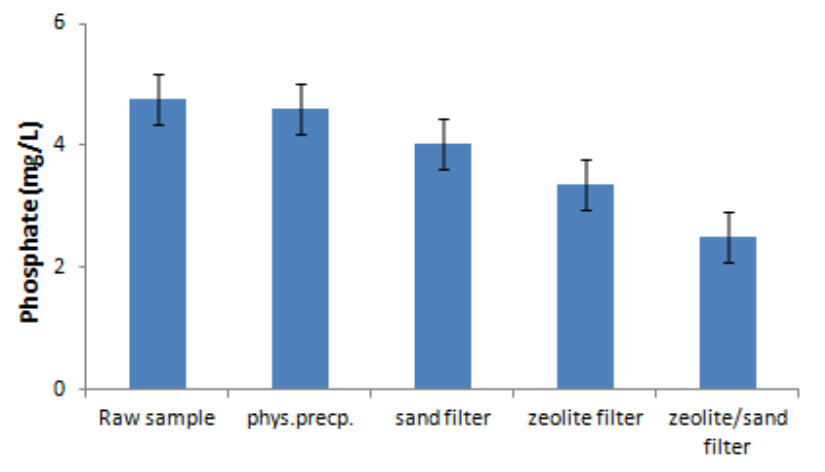

Figure 7. Impact of different treatment steps on soya bean oil mill wastewater on Phosphate $(\mathrm{mg} / \mathrm{L})$.

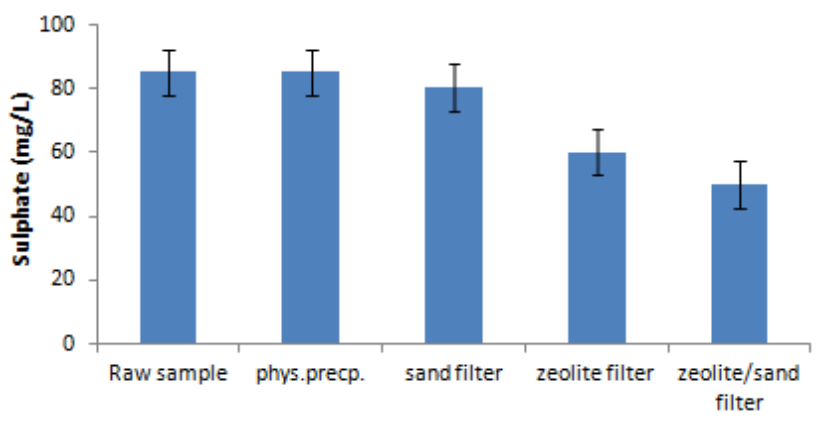

Figure 8. Impact of different treatment steps on soya bean oil mill wastewater on Sulphate $(\mathrm{mg} / \mathrm{L})$.

\section{Conclusion}

Several methods have been reported for Soya bean oil mill wastewater treatment; however very little research has been done on the treatment of soya bean oil mill wastewater using zeolite Y. In this present study, a simple zeolite low-cost method was used for Soya bean oil mill wastewater treatment. The treatment of soya bean oil mill wastewater using successive columns of fine sand, zeolite and zeolite/sand composite decreased the concentration of, $\mathrm{pH}, \mathrm{NO}_{3}^{-}, \mathrm{SO}_{4}^{2-}, \mathrm{PO}_{4}^{3-}$, Turbidity, alkali and alkaline earth metals such as $\mathrm{Mg}^{2+}, \mathrm{Ca}^{2+}, \mathrm{K}^{+}$ and $\mathrm{Na}^{+}$which potentially increases soil salinity [33]. This method has proved to be effective in the treatment of soya bean oil mill wastewater.

\section{References}

[1] Soetan, K. O., Yan Wu. (1968). Flame Photometric Analysis of Sodium and Potassium in Nanogram Samples of Mammalian Nervous Tissue. Journal of Neurochemistry, 15 (7): 547-562.

[2] Varga, M., Takács, M., Záray, G. and Varga, I. (2013). Comparative study of sorption kinetics and equilibrium of chromium (VI) on charcoals prepared from different low-cost materials. Journal of Micro Chemical Science, 107: 25-30.

[3] Kaya, C. A., B. E. Higgs, D. (2003). Response of salt-stressed strawberry plants to supplementary calcium nitrate and/or potassium nitrate. J. Plant Nutrition. 26: 543-560. 
[4] Wei, C. Zhang, T. Feng, C. Wu, H. Deng, Z. Wu, C. Lu, B. (2011). Treatment of food processing wastewater in a fullscale jet biogas internal loop anaerobic fluidized bed reactor. Journal of Biodegradation, 22, 347-357.

[5] Northcort, K. A, Bacus, J, Taya, W, Kamatsu, Y, Perera, J. M, Stevens, G. W. (2010). Synthesis and Characterization of hydrophobic zeolite for the treatment of hydrocarbon contaminated ground water., Journal of Hazard Material. 184: 434-440.

[6] Abramovi, H, Abram, V. (2005). Physico-Chemical Properties, Composition and Oxidative Stability of Camelina sativa Oil. Journal of Food Technology and Biochemistry. 43 (1): 63-70.

[7] Wang, s, Peng, Y. (2010).. Natural zeolites as effective adsorbent for wastewater treatment. Journal of Chemical Engineering. 156, 11-24.

[8] APHA, American Public Health Association Standard Methods for the Examination of Water and Wastewater, APHA, New York, NY, USA, 22nd edition, 2012.

[9] Hansen, C. L and Cheong D. Y. (2007). Agricultural Waste Management in Food Processing, in Handbook of Farm, Dairy, and Food Machinery, edited by: Myer Kutz, William Andrew Publishing, was untreated soya bean oil mill wastewater US, 609-661, Chapter 20.

[10] Handojo, D. U and Mohd, R. S, (2007). Adsorption of Heavy Metals from Water and Wastewater Using Low Cost Adsorbents from Agricultural By-Products, Asian Journal of water, environment and pollution 6 (2): 73-80.

[11] Vishnuprasad, K. Senthil, K. (2015). Adsorption studies on treatment of cooking oil mill effluent using crab shell chitosan Journal of Chemical and Pharmaceutical Research, 7 (11): 19-29.

[12] Halim, S. I., Shazryenna. D, Syafiie. S, Shamsul. I. (2013). A Study on Zeolite Performance in Waste Treating Ponds for Treatment of Palm Oil Mill Effluent, Journal of Water Resource and Protection.

[13] Ahmaruzzaman, M. (2008). Adsorption of phenolic compounds on low-cost adsorbents: A review. Journal of Advanced Colloid Interface Science, 1 (2): 48-67.

[14] Anagnostopoulos, V and Symeopoulos, B. (2013). Sorption of europium by malt spent rootlets, a low-cost bio sorbent: effect of $\mathrm{pH}$, kinetics and equilibrium studies. Journal of Radio analytical and Nuclear Chemistry, 7 (13): 295-298

[15] Ansari, R and Mosayebzadeh, Z. (2010). Removal of basic dye methylene blue from aqueous solutions using sawdust and sawdust coated with polypyrrole. Journal of the Iranian Chemical Society, 7 (2): 339-350.

[16] Auta, M and Hameed, B. H. (2013). Coalesced chitosan activated carbon composite for batch and fixed-bed adsorption of cationic and anionic dyes. Journal of Advanced Colloid Interface Science 2 (6): 199-206.

[17] Bansal, M., Singh, D., Garg, V. K and Rose, P. (2009). Use of Agricultural Waste for the Removal of Nickel Ions from Aqueous Solutions: Equilibrium and Kinetics Studies. International journal of civil and environmental engineering, 1 (2): 108-114.

[18] Hasan N. Y., Abdullah, S. Al-Farraj., (2014). Olive mill wastewater treatment using a simple zeolite-based low-cost method Journal of Environmental Management 145: 341-348.

[19] Bhatnagar, A and Minocha, A. K. (2006). Conventional and non-conventional adsorbents for removal of pollutants from water- A review. Indian Journal of Chemical Technology, 3 (13): 203-217.

[20] Abdelgadir, E. M., Fadul, E. M., Fageer, E. A and Ali, E. A. (2010). Response of wheat to nitrogen fertilizer at reclaimed high terrace salt-affected soils in Sudan. Journal of Agriculture \& Social Sciences, 6 (5): 43-47.

[21] Alluri, H. K., Ronda, S. R., Settalluri, V. S., Bondili, V. S., Suryanarayana, V., Venkateshwar, P. (2007). Bio sorption: An eco-friendly alternative for heavy metal removal. African Journal of Biotechnology. 6 (11): 2924-2931.

[22] Babel, S. and Kurniawan T. A., (2003). Low-cost adsorbents for heavy metals uptake from contaminated water: a review. Journal of Hazard Material, 3 (97): 219-243.

[23] Diez, V., Ramos, C., Cabezas. J. L. (2012). Treating wastewater with high oil and grease content using an anaerobic membrane bioreactor (AnMBR), Filtration and cleaning assays. Journal of Water Science Technology, 65: $1847-1853$

[24] Zagklis, D. P., Arvaniti, E. C., Papadakis, V. G., Paraskeva, C. A., (2013). Sustainability analysis and benchmarking of olive mill wastewater treatment methods. Journal of Chemical Technology, 5 (88): 742-750.

[25] Saravanakumar, K., Kumar, A., (2013). Removal of phenol from aqueous solution by adsorption using zeolite. African Journal of Agricultural Research 8: 2965-2969.

[26] Sridhar, S., Kale, A., Khan, A. A. (2002). Reverse osmosis of edible vegetable oil industry effluent. Journal of Membrane Science, 83: 203 -205.

[27] Priyanka. R., Pameli, P., Sherry, H. S., Sharma, M., Tomar, R., Bhardwaj, M. (2017). Performance of zeolite powder and tubular membrane having different ration for removing As (III) in aqueous phase. International journal applied Ceramic Technology, 14 (3): 227-292.

[28] Ersahin, M. E., Ozgun, H., Dereli, R. K., Ozturk, I. (2011). Anaerobic treatment of industrial effluents: An overview of applications. In Wastewater Treatment and Reutilization; Journal of water reuse and desalination, 3 (7): 39-45.

[29] Chipasa, K. B., (2001). Limits of Physicochemical Treatment Of Wastewater in the Vegetable Oil Refining Industry, Polish Journal of Environmental Studies, 10 (3): 141-147.

[30] Fia, R. L.; Matos, A. T., Borges, A. C., Fia, R., Cecon, P. R., (2012). Treatment of wastewater from coffee bean processing in anaerobic fixed bed reactors with different support materials: Performance and kinetic modeling. Journal Environmental Management, 108: 14-21.

[31] Pitakpoolsil, W. and Hunsom, M. (2013). Adsorption of pollutants from biodiesel wastewater using chitosan flakes. Journal of the Taiwan Institute of Chemical Engineers, 44: 963-971.

[32] Gupta. V. K., Nayak, A., Agarwal, S., Dobhal, R., Uniyal, D. P., Singh, P., Sharma, B., Tyagi, S. and Singh, R., (2012). Arsenic speciation analysis and remediation techniques in drinking water, Desalination and Water Treatment, European Journal of Environmental Science, 40 (3): 231-243. 
[33] Sarita Sharma 1. Ashok, K. Sharma 1, Sanjay Verma 1, Himmat Singh Dodiya, (2014). Edible oil refinery waste water treatment by using effluent treatment plant, International Journal of Chemical Studies 2: 3-10. 